\title{
The Prostitution Business of Greater Mekong Subregion Women in Bangkok and the Adjacent Areas
}

\author{
Jomdet Trimek $^{1}$, Kittisak Jermsittiparsert ${ }^{1,2}$, Noppon Akahat ${ }^{2,3}$, Sarunyaphat Sieangsung ${ }^{3} \&$ Sunisa Ratchaphan $^{2}$ \\ ${ }^{1}$ College of Government, Rangsit University, Pathumthani, Thailand \\ ${ }^{2}$ Political Science Association of Kasetsart University, Bangkok, Thailand \\ ${ }^{3}$ Faculty of Social Sciences and Humanities, Mahidol University, Nakhon Pathom, Thailand \\ Correspondence: Jomdet Trimek, College of Government, Rangsit University, Pathumtani, Thailand. Tel: \\ 66-8-6989-4460. E-mail: jomdet@rsu.ac.th
}

Received: October 16, 2015 Accepted: November 23, 2015 Online Published: February 2, 2016

doi:10.5539/res.v8n1p35 URL: http://dx.doi.org/10.5539/res.v8n1p35

\begin{abstract}
This paper is a qualitative based research, conducting in-depth interviews with 18 subjects consisting of GMS prostitutes working in Bangkok and other relevant informants. The objectives of this research are to study characteristics of the prostitution business in Bangkok and the adjacent areas and to study dynamics of causes, motivation, and the processes of how GMS women entering the prostitution business in Bangkok. The research results show that the entertainment places secretly provide prostitution services in Bangkok and the adjacent areas run the business openly. GMS women and Thai women providing prostitution services is illegal in Thailand. GMS women travelling to Bangkok to provide the prostitution services come from Laos, Myanmar, Vietnam, China, and Cambodia, respectively. Although the government takes strict action, the prostitution business cannot be completely eradicated. The most important problem is corruption of government officials in various areas. As for the recommendations, it is advised that there should be a study of international practices consisting of crime control models, especially elimination of corruption of government officials in various areas, legalization model, or decriminalization model in the offence of the prostitution service to study the models suitable for the current situations.
\end{abstract}

Keywords: prostitution, Greater Mekong Subregion, Thailand

\section{Introduction}

The occurrence of capitalism, higher cost of living, and insufficient incomes of each family increasingly affect deviant behavior, crime behavior, or illegal careers under perspective of criminologists (Merton, 1938). The problem of the prostitution business and the problem of prostitutes violate the law of Thailand and Greater Mekong Subregion (GMS) and have to be solved in the present time.

"Thailand is one of the most notorious places of the trafficking in women and children for the prostitution" (Romanow, 2012). The entertainment places with the prostitution service openly provide the service on Ratchada Road, New Phetchaburi Road, Rama IX Road, and Sukhumvit Road. Although the mentioned activity is illegal in Thailand (Physicians for Human Rights, 2004), the prostitution service is openly provided without legal fear. Apart from Bangkok, GMS women provide the prostitution service in the provinces adjacent to Bangkok. Due to the Order of National Council for Peace and Order no. 100/2014 dated $21^{\text {st }}$ July 2014 relating to Monitoring Management of the Problems of Alien Labors and the Trafficking in Persons in Bangkok (The Order of National Council for Peace and Order, 2014), Bangkok is strictly controlled about the prostitution service, especially GMS women, labors, and children, causing change of the prostitution business in Bangkok.

However, the entertainment places secretly providing the prostitution service in Bangkok still openly provide the services. The researcher, therefore, wanted to study characteristics of the prostitution business in Bangkok and the adjacent areas and study dynamics of causes, motivation, and process of GMS women entering the prostitution business in Bangkok to lead to the guidelines on solution to the mentioned problem.

\section{Methodology}

This is the qualitative research by the in-depth interview (Jubb, 1998). There are 18 key informants being 
Chinese, Vietnamese, Myanmar, Lao, Cambodian, and Thai women providing the prostitution service in Bangkok and concerning informants as follows:

As for relevant subjects from China, two Chinese women are prostitutes in a massage parlor. And a Chinese woman provides the service in a pub \& bar secretly providing the prostitution service. As for related people from Vietnam, a Vietnamese woman is a prostitute in a snooker shop secretly providing the prostitution service. A Vietnamese man is a receptionist. And a Vietnamese woman is a prostitute in a massage parlor. As for related people from Myanmar, three Myanmar women provide the services in a restaurant secretly providing the prostitution service. And one of these three women also provides the service in a massage parlor. As for related people from Laos, a Lao woman provides the service in a karaoke shop secretly providing the prostitution service. A Lao woman provides the service in a snooker shop. And a Lao woman provides the service as a sideline woman. As for related people from Cambodia, three Cambodian women provide the service in a karaoke shop secretly providing the prostitution service. As for related people from Thailand, a Thai man is a receptionist in a restaurant. A Thai man is a receptionist in a massage parlor. And a Thai man is an agent contacting sideline women.

\section{Results}

\subsection{Types of Service Provision Related to the Prostitution Service of GMS Women in Bangkok and the Adjacent Areas}

Types of service provision related to the prostitution service of GMS women in Bangkok and the adjacent areas are divided by the researcher into five groups as follows:

\subsubsection{Massage Parlors}

The massage parlors are the most popular and most easily accessible entertainment place for buying the prostitution service in Bangkok and other cities throughout Thailand. However, there is the highest competition on this service provision in Bangkok where the massage parlors have very high investment when compared with the massage parlors in other provinces. There are a lot of massage parlors on Ratchadaphisek Road, Rama IX Road, and New Phetchaburi Road. Each massage parlor openly provides the prostitution service and police officers well know that these massage parlors provide the prostitution service. Despite the law prohibiting the prostitution service, these massage parlors are still openly implemented.

Massage parlors are permitted to be operated according to Entertainment Places Act. B.E. 2509, Section 3 (3) amended by the Second Entertainment Places Act. B.E. 2525. The massage parlors are places for bathing, massaging, or taking a sauna. People are able to provide the service for customers in the massage parlors. The prostitution service or the prostitution business is prohibited according to Section 11 of Prostitution Prevention and Suppression Act. B.E. 2539 with the highest imprisonment of 15 years and the highest fine of 300,000 baht for persons arrested and proved to be operators of the sex trade business.

However, the massage parlors in Bangkok and the adjacent areas affix the signs prohibiting the prostitution service both in the reception area and private rooms for use as an excuse that the prostitution service is not provided. However, all customers know that they are able to buy the prostitution service at these massage parlors. And receptionists openly inform service users about characteristics of sex service provision of service providing staffs. Service charges each time are 1,500-10,000 baht per two hours. Service charges of each massage parlor are different, depending on physical appearance of children providing the service, location, and facilities of the entertainment places.

After interviewing a man who is a receptionist in the massage parlor, the researcher found that the massage parlor also secretly provides the prostitution service. And GMS women also provide the prostitution service in the massage parlor. Very few entertainment places employ GMS women to be prostitutes because the entertainment places owners have to pay 10,000 baht per an agency of police officers. If the massage parlors do not provide the prostitution service of foreign women, they have to pay police officers about 200,000 baht per month (different expenses depending on the areas and period of strict law enforcement). If the massage parlors also provide the prostitution service of foreign women, they have to pay police officers 400,000 baht per month. Moreover, the massage parlors owners have to have power or be close to powerful people in Thailand, soldiers, police officers, or politicians. Despite the order of the National Council for Peace and Order on monitoring management of the problems of alien labors and the trafficking in persons in Bangkok, two massage parlors on Rama IX Road and two massage parlors on Ratchadaphisek Road still provide the service of GMS women. Service women most considerably found come from Myanmar, followed by Laos, Vietnam, China, and Cambodia, respectively. This will be detailed in the part of the interview. 


\subsubsection{Pubs \& Bars Secretly Providing the Prostitution Service}

Pubs \& bars offer music performance. According to Entertainment Places Act. B.E. 2509, Section 3 (2), pubs \& bars are places where food, liquor, tea, or other drinks are sold and service women have to take care of customers. Relaxation places and massage service are provided for customers. Like the massage parlors, pubs $\&$ bars clearly affix the signs stipulating that the prostitution service is prohibited. However, service women secretly provide the prostitution service in pubs \& bars.

In the past, pubs \& bars provided the services as "tea shops". Service users well know that the tea shops provided the services with women taking care of customers and secretly providing the prostitution service. Social change and additional receipt of western influence in the present time makes service provision in the form of tea shops disappear but brings about service provision in the form of pubs \& bars. According to Entertainment Places Act. B.E. 2509, Section 3 (4), pubs \& bars are places where food, liquor, tea, or other drinks are sold and music or other performances are shown for entertainment. However, the mentioned entertainment places also provide service women. At present, these service women called "drink women" have to take care of customers by serving liquor or talking with customers. Service users are able to sufficiently touch these drink women and have to pay 150-600 baht per drink. These drink women are able to ask customers to limitlessly drink, depending on agreement of service users and service providers. This service provision is very popular among Thai female adolescents who want to make more incomes without the prostitution service and meet the need of materialistic society. However, the prostitution service is still provided in the pubs \& bars. The prostitution service charges are 3,000-10,000 baht because these service women have good physical appearances and higher social status than service women in the massage parlors.

GMS women rarely provide this service when compared with other services because a lot of Thai women mainly provide the mentioned service. The researcher found that Chinese women provide the mentioned service in pubs \& bars on Rama III Road in Bangkok being the entertainment places welcoming tourists from China visiting or working in Thailand.

\subsubsection{Restaurants and Karaoke Shops Secretly Providing the Prostitution Services}

Restaurants and karaoke shops provide the services with lower service charges than the first two entertainment places. Restaurants in Bangkok and the adjacent areas secretly providing the prostitution service are rarely seen when compared with karaoke shops. The famous Chinese restaurant secretly providing the prostitution service on Rama VI Road has provided the service for more than 50 years. There are private rooms in this restaurant where 10 customers are able to use the service in each private room. While dining, customers are able to call for service women to take care of them. After interviewing a male receptionist in this Chinese restaurant, the researcher found that customers are able to request service women to take off their clothes with the service charge of 200 baht per time for taking off the upper part of clothes and 500 baht per time for taking off all clothes. After service women take off their clothes each time, they will rub their naked part with all customers. If customers want these service women to take off all clothes and sit with them, they have to pay 1,000 baht per hour for the service charges. Moreover, these service women also provide the prostitution service supported by this restaurant. If customers want to buy the prostitution service, they have to pay 2,500 baht for the service charges. The restaurant will deduct the mentioned service charge by 500 baht and the hotel expenses by 400 baht while service women will receive the wages of 1,600 baht per a prostitution service. This restaurant does not fix work period and do not give service women salary. There are 20 service women per day. 43 service women in this restaurant come from Myanmar. The interesting issue is that this restaurant received a hygienic restaurant certificate from Bangkok Metropolitan Administration and Health Department, Ministry of Public Health in 1998 although it is generally known that this restaurant also provides the prostitution service. Although police officers have examined this restaurant for several times throughout 50 years, they arrest prostitutes who illegally immigrate and do not have work permits only (Manager Newspaper, 2012). However, this restaurant still provides the service despite strict policy on suppression of the prostitution service and the trafficking in persons.

Like restaurants, karaoke shops procure girls to take care of customers but very cheap price. Most of karaoke shops are not situated in Bangkok due to higher expenses comparing to the suburban areas. However, karaoke shops secretly provide the prostitution service for Japanese tourists in the heart of Bangkok. Most of these karaoke shops are situated on Sukhumvit Road where a lot of Japanese people live. According to the interview, the researcher found that karaoke shops in the suburban areas adjacent to Bangkok are called Larp karaoke shops because most of these shops employ Lao people to provide the service and these shops sell E-san food or Lao food. The first area the researcher would like to mention is Highway No. 304, Chachoengsao Province where a lot of Lao people illegally immigrate to work as drink women in the Larp karaoke shops and a lot of Larp 
karaoke shops are situated in this area. Like tea shops, these karaoke shops sell food and drinks and allow service women to take care of customers. However, these shops are very small and do not have the licenses for provision of 2-5 karaoke vending machines. Customers are able to call service women to take care of themselves and have to pay $60-120$ baht per drink. Moreover, these shops secretly provide the prostitution service and provide the service of accommodations behind the shops. If customers want to buy the prostitution service, they have to pay about 700-1,000 baht only. This price will be deducted for the shops about 300 baht and the room service about 100 baht while those Lao women receive 300-600 baht per time. After the order to eliminate the prostitution service and the trafficking in person, karaoke shops in these areas completely cease the business. However, the mentioned prostitution service still exists and is changed as "Sideline Women Service.

Moreover, the researcher went to Soi Manhatton Hotel, Khlong Luang District, Pathum Thani Province where there are a lot of karaoke shops being not different from those in Chachoengsao Province but having higher prostitution service charges of 1,200-2,000 baht. Thai, Lao, Myanmar, and Cambodian women provide the prostitution service here. Moreover, there are karaoke shops in Soi Flat Pla Thong with the same characteristics and price as those in Soi Manhatton Hotel. The interesting issue is that although police officers are always in a police booth situated at the middle of this soi, these karaoke shops openly provide the service as if there were no police officers or the law could not be completely enforced (Durkheim, 1951). According to the interview, the researcher found that these karaoke shops have to pay police officers both area police officers and police officers of various agencies 2,000 baht per agency. A karaoke shop has to monthly pay 8,000-10,000 baht. This will be detailed in the part of the interview.

\subsubsection{Other Entertainment Places Secretly Providing the Prostitution Service}

The researchers have determined other entertainment places and found them to be different from the above three entertainment places because there are several entertainment places secretly providing the prostitution services. For example, the prostitution service is secretly provided in traditional massage parlors, snooker shops, or barbershops. However, other entertainment places do not seek permission to be entertainment places according to Entertainment Places Act. B.E. 2509 but they provide the service by seeking permission according to other act. For example, a snooker shop is a kind of gambling according to List Khor. No. 23 in accordance with Gambling Act. B.E. 2478. According to the mentioned law, Section 4, Paragraph 2, the snooker shops established to bring about an organizer's benefits, directly or indirectly, has to be permitted from the officials. Ministry of Interior issued a letter no. 15477/1961 dated 25 September 1961 to prohibit the issue of a license for the mentioned business from $1^{\text {st }}$ January 1962. Most of snooker shops are currently implemented without the licenses. Service women take care of customers around snooker tables and also secretly provide the prostitution service in the rooms on the second floor of the shops. And GMS women also provide the service in these snooker shops. The researcher interviewed the victims in the snooker shop in Minburi area where Vietnamese and Lao people provide the service. This will be detailed in the part of the interview.

A traditional massage parlor or "massage by pretty women" or "Krapoo Massage" has to seek permission to provide the service of "Heathy Spa Business" which is health care business operation according to the notification of Ministry of Public Health issued in accordance with Public Health Act. B.E. 2535 (Public Health Law) and Entertainment Places Act. B.E. 2509 (Entertainment Places Law) amended by The Fourth Entertainment Places Act. B.E. 2546. This business provides the service of specific massage and secretly provides the prostitution service. However, the service charges in this entertainment place are lower than service provision in a massage parlor if a customer informs the massage parlor owner about no intercourse. If the customer wants intercourse, he has to privately inform a service provider. This service is widely provided in the present time. This spa business is continuously operated throughout Bangkok and secretly provides the prostitution service of GMS women less than the massage parlor because a lot of Thai women are pleased to provide the service in such manners and are able to create a lot of income without the prostitution services.

\subsubsection{Sideline Women Service}

The sideline women service is service provision with direct contact between a procurer or an agent and a service user. Due to no specific service provision places, it is not necessary to seek permission from the government. This service has been provided in Thailand for a long time, especially in Bangkok and various cities throughout the country where customers have considerable purchase power. After interviewing the agent procuring GMS women to provide the service of "sideline women", the researcher found that as karaoke shops are urgently suppressed, this business cannot be operated. As there are a lot of old customers and a lot of unemployed women want to provide the prostitution service after the government's attempt to sweep out such karaoke business, those karaoke owners then consequently become "sideline women agents" instead and directly contact old customers 
who used to use the service of karaoke shops. Due to more customers by word-of-mouth and development of communication technology in the present time, especially the role of "Line" Application, the prostitution service can be more conveniently provided. The sideline women agents are able to contact more customers and more quickly send prostitutes' photos. Provision of this service is continuously popular among customers and Thai and GMS women wanting to provide the prostitution service. The researcher interviewed Lao women providing this service.

\subsection{The Results of Interviewing GMS Women about the Prostitution Business in Bangkok and the Adjacent Areas}

The results of interviewing GMS women about the prostitution business in Bangkok and the adjacent areas are as follows:

\subsubsection{Chinese Women}

The researcher interviewed two prostitutes working in a massage parlor and a woman providing the service in a pub \& bar secretly providing the prostitution service with details as follows:

After interviewing the first Chinese woman, the researcher found that she comes from Yunan and has worked in a massage parlor on Rama IX Road for five months because her family has low incomes and her elder sister has done this work in Thailand for eight years. This Chinese woman mentioned her family dwelling and the reasons why she enters Thailand to provide the prostitution service as follows:

"My family in Yunan has 100 rubber trees. My parents receive 1,000 baht for tapping the rubber each time. Due to insufficient incomes, I help my parents do work but I feel very tired and hot. As my elder sister has worked for eight years in Thailand, I make decision to do the same work as her in Thailand"-The first Chinese woman

The first Chinese woman completes the senior high school education and does not further her study. As her elder sister told her that she does this work in Bangkok, is able to make a lot of money, and send her parents money, the first Chinese woman rationally makes decision to do this work like her elder sister (Becker, 1976). Her mother well knows about her work and her elder sister's work while her father only knows that she works in Thailand. The first Chinese woman said that this service cannot be provided in Yunan. Due to very strict enforcement of law, she cannot do this work in China. She goes to Bangkok to do this work because her elder sister does this work and she fears sexual disease if she goes to other places. She informed the researcher about the reasons why she provides the prostitution service in Bangkok as follows:

"I cannot do this work in Yunan. I used to think that I would do this work in Mae Sai but my friend used to do this work in Mae Sai and had AIDS so I decided to do this work in Bangkok because my elder sister said that it was safer"-The first Chinese woman

The first Chinese woman said that she receives the service charges of 2,800 baht per time. This shop gives her 1,400 baht only. Throughout the period of five months, she is able to send her parents more than 100,000 baht. Chinese women providing this service enter Chiang Rai and go to Bangkok by a van.

The second Chinese woman said that she comes from 12 Panna and has lived in Thailand for over two years. She more clearly speaks Thai language than the first Chinese woman. As her friend doing this work told her that she is able to create incomes exceeding 100,000 baht per month so she decides to go to Thailand. Her family is rather rich and has the gold-selling shop in China. Before going to Thailand, she monthly receives salary of 25,000 baht for working in her family's gold-selling shop in China. However, she thought that her salary is insufficient and she believed that she is able to make a lot of money if she goes to Thailand.

"During the first year I came here to do this work, I am able to create the incomes of 100,000 baht. In the second year, I only receive about 40,000 -50,000 baht per month so I think that I will return to China"-The second Chinese woman

The financial factor makes these women continue doing this work. The second Chinese woman added that it is more difficult to make money due to strictness in Thailand. The interesting issue is that Chinese women similarly believe that this work is lawful in Thailand. As a lot of customers are Thai soldiers and police officers, Chinese women doubt whether this service provision is legal.

The third Chinese woman specifically provides the service for Chinese tourists in a pub on Rama III Road. As she cannot speak Thai, the researcher interviewed her through an interpreter who can speak both Thai and Chinese. Her physical appearance is better than that of Chinese women providing the service in the massage parlors. This entertainment place specifically selects women with good physical appearance to provide the service for customers in the form of "Drink Women". The third Chinese woman has worked in Bangkok for a 
month through the contact with Chinese agents. She receives 300 baht per drink and is able to make money exceeding 10,000 baht every night. Moreover, the prostitution service is also secretly provided here. The third Chinese woman said that it is an agreement between her and the customer. If she agrees to provide the prostitution service, she has to deduct her incomes $30 \%$ per time for the shop. The prostitution service charges of the third Chinese woman are 50,000 baht per time which are very high service charges when compared with the first two Chinese women due to characteristics of service provision, place, and service users who are Chinese businessmen and tourists.

If the prostitution service or operation of the prostitution business is considered as commission of the offence, women increasingly violate the law. Change of the status of women by participation in the labor market and earning their living enables women to have more opportunities to violate the law for living (Simon, 1975).

\subsubsection{Vietnamese Women}

As for relevant informant from Vietnam, a Vietnamese woman works as a prostitute in a snooker shop secretly providing the prostitution service. A Vietnamese man is a receptionist. And a Vietnamese woman works as a prostitute in a massage parlor. The first person who the researcher wanted to mention is a Vietnamese man who is a receptionist and brings Vietnamese women to this place. This Vietnamese man said that Vietnamese women like to be waitresses in restaurants in Bangkok because they are able to receive higher remunerations and earn extra money from customers eating food at the restaurants. He used to be a receptionist in a restaurant on Prachachuen Road where Vietnamese women are waitresses. If customers want to take these waitresses outside the restaurant, they have to pay 400 baht to the shop and bargain with these women about the price. The service charges are 1,000-3,000 baht. This Vietnamese man said that a snooker shop asks him to procure women to provide the service in this snooker shop. He said that Vietnamese people working in Thailand are first persuaded to work in the restaurants and learn to do the prostitution work. He said that Vietnamese women doing this work in Thailand are able to create more money than those in Vietnam. As the appearances of Vietnamese women attract Thai tourists, it is easy for these women to work in Thailand. The Vietnamese man said that this snooker shop has to pay 10,000 baht per unit to police officers and monthly pay 50,000 baht to police officers. After additionally interviewing this Vietnamese man for the second time, the researcher found that the area police officers and soldiers arrested four alien women while the mentioned snooker shop still provides the prostitution service of Thai women. The first Vietnamese woman interviewed by the researcher in a snooker shop is only 17 years old and used to be a waitress in the Minburi area. After that, she was persuaded to provide the prostitution service in this snooker shop. She said that the prostitution service is also provided in Vietnam. Her friend told her that the service charges of the prostitution service in Vietnam are 500 baht only. After deduction of the entertainment place, the service providers only receive $300 \mathrm{baht}$. This stimulates service providers to make more incomes (Merton, 1938). In the meantime, the prostitution service charges in Thailand are 2,400 baht. After deduction of the shop, service providers receive 1,200 baht per time. The first Vietnamese woman mentioned the GMS prostitution situations as follows:

"Thai people prefer Vietnamese people. It is easy to find work in Thailand, either waitresses in restaurants or the prostitution service. Wages in Thailand are higher than those in Vietnam. Waiters or waitresses in Vietnam only receive 100 baht per day while waiters or waitresses in Bangkok receive 500 baht per day (inclusive of a tip). Sometimes, they receive more than 1,000 baht"-The first Vietnamese woman

After interviewing the second Vietnamese woman, the researcher found that it is easy for her to do this work in Thailand and Laos because Thai and Lao men like Vietnamese women. However, working in Bangkok creates more incomes.

According to the second Vietnamese woman, aged 27 with the prostitution experience for over 10 years, the entertainment place owners in Vietnam more secretly provide the prostitution service than those in Thailand. The prostitution service cannot be provided on the main roads like Bangkok. The prostitution service has to be secretly provided on the building under contact with the agents and agreement with the agents for the service charges. Service provision is similar to that of the massage parlors and sideline women. This Vietnamese woman travels to Thailand by car. Most of Vietnamese women work in two cities consisting of Bangkok and Pattaya. It can be said that Vietnamese women can be widely found in restaurants, massage parlors, and all secret entertainment places because Thai tourists prefer these female prostitutes.

\subsubsection{Myanmar Women}

The researcher interviewed three Myanmar women working in a restaurant secretly providing the prostitution service. One of these three women also provides the service in a massage parlor. Myanmar people most 
considerably migrate to work in Thailand by being labors in the construction industry, fishing industry, restaurants, or providing the prostitution service. However, most of Myanmar people entering the prostitution business are Thai Yai people and their appearances attract service users. These three Myanmar women willing to give the information completes the primary education and are able to well speak Thai. The first and the second women sell things at their houses while the third Myanmar woman is unemployed. These three women are persuaded to work here. As women's social status is not equal to men's social status, women enter the prostitution service (Messerschmidt, 1986).

The interview was done at a restaurant secretly providing the prostitution service. The researcher found that these three Myanmar women do not receive any salary but receive the remunerations of 200 baht per time for taking off the upper part of their clothes and 500 baht for taking off all clothes. The prostitution service charges of women are 2,500 baht. After deduction of hotel expenses and the shop expenses by 900 baht, these women receive 1,600 baht per time. The first Myanmar woman said that

"I want the customers to take me outside because I can make more money. If I sit here all day, I receive less than a thousand bath"-The first Myanmar woman

The second Myanmar woman similarly added that she wants the customers to buy the prostitution service as follows:

"If I only sit to take care of the customers, I receive 1,000-2,000 baht per day. If I also go to the hotel with the customers, I receive 5,000 baht per day. My average incomes are 100,000 baht per month"-The second Myanmar woman

The third Myanmar woman similarly added that the prostitution service here creates more money than working in the massage parlor.

"I also work in the massage parlor on Ratchada Road. The service charges are 1,800 baht per time and I receive 1,000 baht only. While working in the massage shop, I am taken to have the medical check-up free. While working here, I have to receive the medical check-up by myself"-The third Myanmar woman

Moreover, customers are able to take Myanmar women to various places all day all night with the expenses of 5,000 baht per day. As for difference in the prostitution service between Thailand and Myanmar, the researcher found that there are few entertainment places with the prostitution service in Yangon, Myanmar. And the prostitution service is Myanmar creates lower income than that in Bangkok.

\subsubsection{Lao Women}

The researcher interviewed several Lao victims because Lao women most considerably provide the prostitution service in Bangkok and the adjacent areas when compared with women of other countries. The researcher analyzed a Lao woman providing the service in a karaoke shop secretly providing the prostitution service, a Lao woman working in a snooker shop, and a sideline woman. The first Lao woman works in a karaoke shop in Chachoengsao. She said that the agents will take Lao women to Thailand by a van by using tourist visa to pass the immigration checkpoint. After arriving at the shop, she was taken to apply for a visa at Pong Nam Ron Checkpoint, Ratchaburi Province. She is able to immediately work there but has to continue working there and report herself to the checkpoint every three months. The first Lao woman informed the researcher about arrest of police officers as follows:

"I used to be arrested. Police officers arrested all prostitutes in the shop and fined us 100 baht per person and released us. After that, the shop owner returned the money to me"-The first Lao woman

The researcher interviewed the second Lao woman at the snooker shop where the researcher used to interview Vietnamese women. Initially, the second Lao woman said that she is a Nongkhai person because she fears that she will be arrested if the researcher is a police spy. After the researcher talked with the shop owner, this Lao woman agreed to be interviewed. The second Lao woman said that this work can be done in Laos and there are a lot of shops with the prostitution service in the northeast of Thailand. However, she decides to work in Bangkok because she does not want her relatives to know that she does this work. This is a cause of women providing the prostitution service in the foreign countries.

The researcher interviewed the third Lao woman and found that she works as a sideline woman by contacting the agents. The third Lao woman said that she used to work in a karaoke shop in Chachoengsao which finally ceased the business. The karaoke shop owner asked her to be a sideline woman. An advantage of working as a sideline woman is that the work period is not fixed. A sideline woman will work if she is called. But the disadvantages 
are that there are no steady incomes. As the places where she goes depend on agreement between the agents and customers, she feels unsafe. As she is not able to do the former work, she has to be a sideline woman until she is able to find the job in a karaoke shop again.

\subsubsection{Cambodian Women}

As for dynamics of causes, motivation, and process of GMS women entering the prostitution service in Bangkok and the adjacent areas, three Cambodian women provide the service in a karaoke shop secretly providing the prostitution service. As the appearances of Cambodian women do not attract Thai customers, Cambodian women doing this work are rarely seen in Bangkok when compared with women coming from other countries. However, the researcher found some Cambodian women working in the entertainment places in Pathum Thani Province. If any karaoke shops have Cambodian women, they do not have women from other countries. These Cambodian women are persuaded to work in these shops. The researcher interviewed a Thai person owning a karaoke shop in Surin Province. He said that he has operated this shop for over five years. Formerly, he was able to more conveniently operate this karaoke shop. After more strictness of the government, it is more difficult to bring Cambodian women to his shop. In a period of three months, the karaoke shop owner is called to see the area police officers at least once. After that, there is determination of the changing expenses. The karaoke shop owner has to monthly pay police officers not less than 10,000 baht. According to the interview, the first Cambodian woman said that she used to work at Bangpu with the remunerations of 300 baht per day. At present, she works in a karaoke shop and receives 80 baht an hour while the prostitution service charges are 1,500 baht which will be deducted by the shop by $20 \%$. The second Cambodian woman additionally mentioned wages here as follows:

"I receive the service charges of 80 baht per hour. Sometimes, I have to sit throughout 24 hours and I can make several thousand baht per day without the prostitution service"-The second Cambodian woman

Apart from karaoke shops, Cambodian women provide the prostitution service at Talad Thai with the service charges of 500-800 baht per time only. Their customers are workers in Talad Thai. Before travelling to Thailand, the first Cambodian woman said that she used to be a waitress. After her mother married a Thai person, she does not stay with her mother and secretly provides the prostitution service. The second and the third Cambodian women said that they go to this karaoke shop through their friends' persuasion. As for living status, these women are able to sufficiently create incomes and rent an accommodation at a price of 3,000 baht. Apart from the sitting service charges, these women monthly receive 6,000 baht. Sometimes, they are able to live without the prostitution service.

\section{Conclusion and Recommendation}

As for the prostitution business in Bangkok and the adjacent areas, there are service provision businesses secretly providing the prostitution service consisting of massage parlors, pubs \& bars, restaurants or karaoke shops, snooker shops, traditional massage, barbershops, and sideline women service. The most popular public entertainment place with the highest investment in the business is the massage parlor which regularly provides the prostitution service despite strictness of the government. The researcher found corruption of government officials in various areas, especially the areas on Rama IX Road and Ratchada Road, enabling these public entertainment places to continue providing the service of GMS women and Thai women.

As for GMS women providing the prostitution service in Bangkok and the adjacent areas, the researcher found that Chinese, Vietnamese, Myanmar, Lao, and Cambodian women come to Thailand to provide the prostitution service. A lot of Lao women come to Thailand to provide the prostitution service, followed by Myanmar women, Vietnamese women and Chinese women, respectively. As the physical appearances of these women considerably attract service users and there is economic recession of those countries, these women travel to Bangkok where they are able to make a lot of money. The corruption problem of the area officials enables this business to continue implementation, being different from law enforcement of other countries in the Greater Mekong Subregion.

According to the abovementioned information, despite strict implementation, the government cannot destroy the illegal prostitution business. The most important problem is corruption of government officials in the areas. If the government wants to completely suppress the sex trade business in Thailand, it has to solve the corruption problem of officials in the areas or find the new guidelines on solution to the mentioned problem by using the policy on legalization and decriminalization with the offence of the prostitution business in Thailand. And these issues should be researched. 


\section{References}

Becker, G. (1976). The Economic Approach to Human Behavior. Chicago: The University of Chicago Press.

David, F. (2007). ASEAN and Trafficking in Persons: Using Data as a Tool to Combat Trafficking in Persons. Geneva: International Organization for Migration.

Derks, A. (2000). Combating Trafficking in South-East Asia: A Review of Policy and Programme Responses. Geneva: International Organization for Migration.

Durkheim, É. (1951). Suicide: A Study in Sociology. Translated by John A. Spaulding and George Simpson. Glencoe, Illinois: The Free Press of Glencoe.

Entertainment Places Act. B.E. 2509

Entertainment Places Act. B.E. 2509

Gambling Act. B.E. 2478

Godwin, J. (2012). Sex Work and the Law in Asia and the Pacific. Bangkok: UNDP.

Hagan, J. (1989). Structural Criminology. New Brunswik, NJ: Rutgers University Press.

ILO. (2011). Cambodia- addressing HIV vulnerabilities of indirect sex worker during the financial crisis: Situation analysis, strategies and entry points for HIV/AIDS workplace education. Bangkok: ILO.

Jubb, V. (1998). Methods of Criminological Research. USA and Canada: Routledge.

Kelly, J. (2004). On The Wrong Side of Development: Human Trafficking for the Sex Trade along the Thai-Burmese Border. Journal of Development and Social Transformation, 1, 13-22.

Laura, B., Lyne, C., \& Julia, N. (2011). Prostituation: A Review of Legislation in Selected Countries. Ottawa: Library of Parliament.

Lee, J. (2005). Human Trafficking in East Asia: Current Trends, Data Collection, and Knowledge Gaps. International Migration, 43(1/2), 165-201.

Manager Newspaper. (2012). Surat Restaurant. Retrieved June 12, 2015 from http://www2.manager.co.th/Around/ViewNews.aspx?NewsID=9550000130708

Merton, R. K. (1938). Social structure and anomie. American Sociological Review, 3(5), 672-682.

Messerschmidt, J. W. (1986). Feminist Criminology. Totowa, NJ: Rowman \&Littlefield.

Physicians for Human Rights. (2004). No Status: Migration, Trafficking \& Exploitation of Women in Thailand. Massachusetts. Physicians for Human Rights.

Prostitution Prevention and Suppression Act. B.E. 2539

Public Health Act. B.E. 2535

Romanow, L. (2012). The Women of Thailand. Global Majority E-Journal, 3(1), 44-60.

Simon, R. J. (1975). Crimes Women Commit. Washington D.C.: Lexington Books.

Tarancon, Al. (2013). Thailand's Problem with the Sexual Exploitation of Women in The 21st Century. Master of Arts Thesis in Liberal Studies, Georgetown University.

The Fourth Entertainment Places Act. B.E. 2546.

The Order of National Council for Peace and Order. (2014). The Order of National Council for Peace and Order no. 100/2014 dated $21^{\text {st }}$ July 2014. Retrieved August 26, 2014 from http://library2.parliament.go.th/giventake/content_ncpo/ncpo-order100-2557.pdf

The Second Entertainment Places Act. B.E. 2525

United Nations Development Programme. (2010). Human Security, Today and Tomorrow. Bangkok: United Nations Development Programme.

United Nations Office on Drugs and Crime. (2013). Transnational Organized Crime in East Asia and the Pacific: A Threat Assessment. Bangkok: United Nations Office on Drugs and Crime. 


\section{Copyrights}

Copyright for this article is retained by the author(s), with first publication rights granted to the journal.

This is an open-access article distributed under the terms and conditions of the Creative Commons Attribution license (http://creativecommons.org/licenses/by/3.0/). 